\title{
Vertical Electrical Sounding to Determine Fracture Distribution At Adumasun Area, Oniye, Southwestern Nigeria.
}

\author{
${ }^{1 *}$ T.A. Adagunodo, ${ }^{1}$ A. Sunmonu, ${ }^{2}$ O.P. Oladejo And ${ }^{3}$ I.A. Ojoawo. \\ ${ }^{I}$ Department of Pure and Applied Physics, Ladoke Akintola University of Technology, P.M.B. 4000, Ogbomoso \\ (Code Number 210001), Oyo State, Nigeria. \\ ${ }^{2}$ Department of Physics, Emmanuel Alayande College of Education, Oyo, Oyo State, Nigeria. \\ ${ }^{3}$ Department of Physics, University of Ibadan, Ibadan, Oyo State, Nigeria. \\ Vertical Electrical Sounding to Determine Fracture Distribution at Adumasun area, Oniye, Southwestern \\ Nigeria.
}

\begin{abstract}
People living in Ibadan, Southwestern Nigeria have started shifting their focus on construction of buildings towards villages that are close to the metropolis. It is therefore imperative to carry out this research in order to recommend the types of structures to be erected at Adumasun area, Oniye, Southwestern Nigeria when the time comes in order to avoid catastrophic failure that might have happened thereafter. The aim of this research is to carry out vertical electrical sounding geophysical survey at Adumasun area, Oniye, Southwestern Nigeria with a view to determining the fracture distribution within the study area. The study area is located between latitude $07^{\circ} 37^{\prime} 55.37^{\prime \prime}$ to $07^{\circ} 38^{\prime} 00^{\prime \prime}$ North and longitude $003^{\circ} 11^{\prime} 10.2^{\prime \prime}$ to $003^{\circ} 11^{\prime} 16.8^{\prime \prime}$ East. Schlumberger electrode array was employed for the study using $R 50$ Resistivity meter for the data acquisition. The geoelectric survey comprised of ten depth soundings, with maximum current electrode spacing $(A B)$ of $200 \mathrm{~m} .40 \%$ of the modeled curves are A-type, 50\% are H-type, and 10\% are KH-type. The geoelectric sections obtained from the sounding curves revealed 3-layer and 4-layer earth models respectively. The models showed that the subsurface layers were categorized into the topsoil, the second layer, and the third layer (where it is present). One-third of the study area showed fresh bedrock while two-third showed fractured bedrock. Areas underlying with fresh bedrock and thin overburden thickness are recommended for the construction of high-rise buildings while areas with fractured basement and thick overburden thickness are recommended for the construction of low-rise buildings. It is concluded that the study area is averagely competent for the construction of high-rise buildings and low-rise buildings depending on where individual builders are located.
\end{abstract}

Keywords:- Fractured Basement, Fresh Bedrock, Geoelectric Section, Overburden Thickness, Precambrian Basement Complex, Vertical Electrical Sounding.

\section{Introduction}

The foundation of a building is that part of walls, piers and columns in direct contact with the ground and the one transmitting loads to the ground. The building's foundation is sometimes referred to as the artificial, and the ground on which buildings foundation is laid as the natural foundation. Ground is the general term for the earth's surface, which varies in composition within the two main groups, rocks and soils. Rocks include hard, strongly cemented deposits such as granite and soil the loose contains uncemented deposits such as clay. Rocks suffer negligible compression and soils measurable compression under the load of buildings. The size and depth of a foundation is determined by the structure and size of the building it supports and the nature and bearing capacity of the ground supporting it (Barry, 1999; Adagunodo, 2012; Adagunodo and Sunmonu, 2013).

Buildings are expected to have certain characteristics that make them attractive for many uses which may be residential, commercial, institutional, educational, and industrial to meet people's daily needs. Characteristics of a good building include provision of security, safety to lives and properties, convenience, in addition to social, psychological and economic satisfactions derived by occupiers. In some cases, buildings that are expected to meet the people's daily needs have become source of great concerns to occupiers, owners, developers, governments, and physical development planning authorities, consequent upon their incessant failure and collapses (Oladejo, 2012).

Building failure, according to Ayininuola and Olalusi (2004), is an unacceptable difference between expected and observed performance of building components. They identified two types of failure in building, which are cosmetic and structural types. Cosmetic failure occurs when something has been added to or subtracted from the building, thus affecting the structures' outlooks. On the other hand, structural failure affects both the outlook and structural stability of the building. Roddis (1993) considered failure as occurring in building components when they can no longer be relied upon to fulfill their principal functions. He distinguished between defect and failure in buildings. Defect is deflection in a building causing certain amount of cracking or 
distortion while excessive deflection that results in serious damage to partitions, ceilings and floor finishes is referred to as building failure. A distressed building exhibits defects in its components, noticeable as weakened foundation, cracks in floors, walls, and roofs. These more often signify overall defects in the structural stability of buildings which, if not checked, result in progressive collapse.

Failure, according to Wardhana and Hadipriono (2003), is the incapacity of a constructed facility or its components to perform as specified in the design and construction requirements. Building collapse is therefore the failure of all or a substantial part of a building, where full or partial replacement may be needed. Citing the collapse of the World Trade Centre tower as the most infamous paradigm, Bazant and Verdure (2006) described progressive collapse as a failure mode of great concern for tall building subjected to fire, internal explosions, external blast, impact, earthquake and foundation movements, and also typical of building demolitions. According to Wardhana and Hadipriono (2003), collapse and distress are subsets of failure in a building. In terms of functionality, collapse occurs when the entire or a substantial part of a structure comes down thereby losing the ability to perform its function. Building collapse may be classified as total and partial collapses. Total collapse implies that several primary structural members of a building have fallen down completely while partial collapse suggests a condition where only some of the primary structural members of the building components have fallen down. Distress is the un-serviceability of a structure or its components that may or may not result in a collapse, and refers to a particular condition of the structure which has undergone some deformations without losing the whole structural integration (Oladejo, 2012).

Incidences of distressed or collapsed buildings are global phenomenon and are not limited to Nigeria. At the international level, a number of building collapses were reported. Ronan Point apartments collapse in U. K. when kitchen gas exploded on the 18th floor sending a 25 -storey building to the ground in 1968; the 2000 Commonwealth Avenue Tower collapse in Boston, 1971; The Civic Center of Pavia in 1989; and collapse of Murrah Federal Building in Oklahoma City in 1995, where air blast pressure caused the collapse of few lower floors while the upper floors failed by progressive collapse. In year 2000, a four-storey commercial building at 14th and 2nd Avenue in Brooklyn, USA, collapsed and vacant building at 124th Street in the north of Manhattan in New York partially collapsed in 2007. Similarly, a five-storey vacant apartment building in Manhattan that earlier appeared to be falling apart for months finally collapsed on March 4, 2008. Other notable collapses include an uncompleted building that showed sign of breaking up in central Nairobi, Kenya collapsed in 2006; an apartment building in downtown Baku, Azerbaijan on August 28, 2007; a twelve-storey apartment building in northern Egyptian port city of Alexandria, Egypt on December 19, 2007; while on 29 March, 2008 in Luanda, Angola, a six-storey police building collapsed with detainees and other people trapped and injured. In May 2008, a wall collapsed at a building site in Farooq Nagar, the suburbs of New Delhi, India; and hotel building consisted of a basement plus three upper floors located opposite Ahmedabad main railway station, Kalupur, India on February 3, 2008 (Oladejo, 2012).

Collapses of buildings have become more intense and devastating in Nigeria today. Many buildings have collapsed because of the subsurface pattern, contrary to opinion which favours insufficiency or lack of genuine building materials. These happened as a result of little or no idea of the people about the subsurface pattern. If buildings are constructed on fractured zones, it may lead to collapse of building in the future depending on the types of buildings constructed and the foundation given to it. High-rise buildings must be avoided on fractured zones while artificial basement should be created before laying foundation of low-rise building cut across fractured zones (Barry, 1999) to avoid collapse. Generally, it is therefore imperative to carry out geophysical survey before the building construction commences and construct the buildings on unweathered basement with thin overburden thickness in order to avoid collapses in the future (Adagunodo, 2012).

Geophysical methods are often used in site investigation to determine depths to the basement and map subsurface characterization prio to excavation and construction. Vertical Electrical Soundings have been used by different authors to determine overburden thickness, fracture distribution, and Geoelectric parameters of subsurface (Nwankwo et al., 2004; Alagbe, 2005; Ayantunji, 2005; Adelusi et al., 2009; Omosuyi, 2010). Adagunodo (2012) and Oladejo (2012) have also applied Vertical Electrical Soundings in their studies to determine the overburden thickness and basement competency at Oyo State Industrial Estate and Oyo State Housing Estate respectively. The resistivity method has its origin in the 1920's due to the work of Schlumberger brothers. For the next 60 years, for quantitative interpretation, conventional sounding surveys were normally used (Koefoed, 1979). In this method, vertical electrical soundings (VES) were conducted using Schlumberger electrode array (Zohdy et al., 1974). The method is suitable for engineering and hydrogeological investigations (Alagbe, 2005).

This study aimed at providing detailed geophysical signatures for overburden thicknesses and fracture distribution of the study area with a view to determining the average depth to basement and to know the competency of the basement with respect to engineering purposes of the area. 


\section{Site Description And Geological Setting.}

Adumasun area is underlain by the Precambrian basement complex of Southwestern Nigeria (Ajibade and Fitches, 1988; Ajibade et al., 1988; MacDonald and Davies, 2000). Precambrian basement comprise of crystalline and metamorphic rocks over 550million years old (MacDonald and Davies, 2000).

The study area is located between latitude $07^{0} 37^{\prime} 55.37^{\prime \prime}$ to $07^{\circ} 38^{\prime} 00^{\prime \prime}$ North and longitude $003^{0} 11^{\prime}$ $10.2^{\prime \prime}$ to $003^{0} 11^{\prime} 16.8^{\prime \prime}$ East. The entire study area is a suburb of Oniye, Oyo State, Nigeria. It is located at some kilometers away from Igangan (Figure 1). Accessibility of the area can be best described in terms of its road network. Several roads dissect the area. These include the major road that link Tapa, Igbo-Ora, and Igangan. Other minor roads and footpaths link the area with other places (like Oniko and Alagbado) (Figure 2). With these roads, the accessibility is very easy.

Two major rock formations exist within the study area. These two rocks are grouped as Migmatite Gneiss complex (e.g. granite gneiss) and Older Granite complex (e.g. granite) (Azeez, 2010). The granite in the region forms the country rock for granite gneiss and banded gneiss. The outcrops are highly weathered and exfoliated, sometimes found with displaced boulders. The granite gneiss is of light and dark mineral layers. Visible minerals include quartz, feldspar and biotite. The rock is highly weathered with potholes resulting from differential weathering. On most locations of gneiss, there is occurrence of folding that is probably due to differential stress. The banded gneiss consists of parallel light and dark coloured bands (Azeez, 2010). Gneiss frequently exists together in outcrops and because of their intimate association, it is not possible to show them as separate units on the geologic map. Figure 3 shows the geologic map of Oniye and the study area.

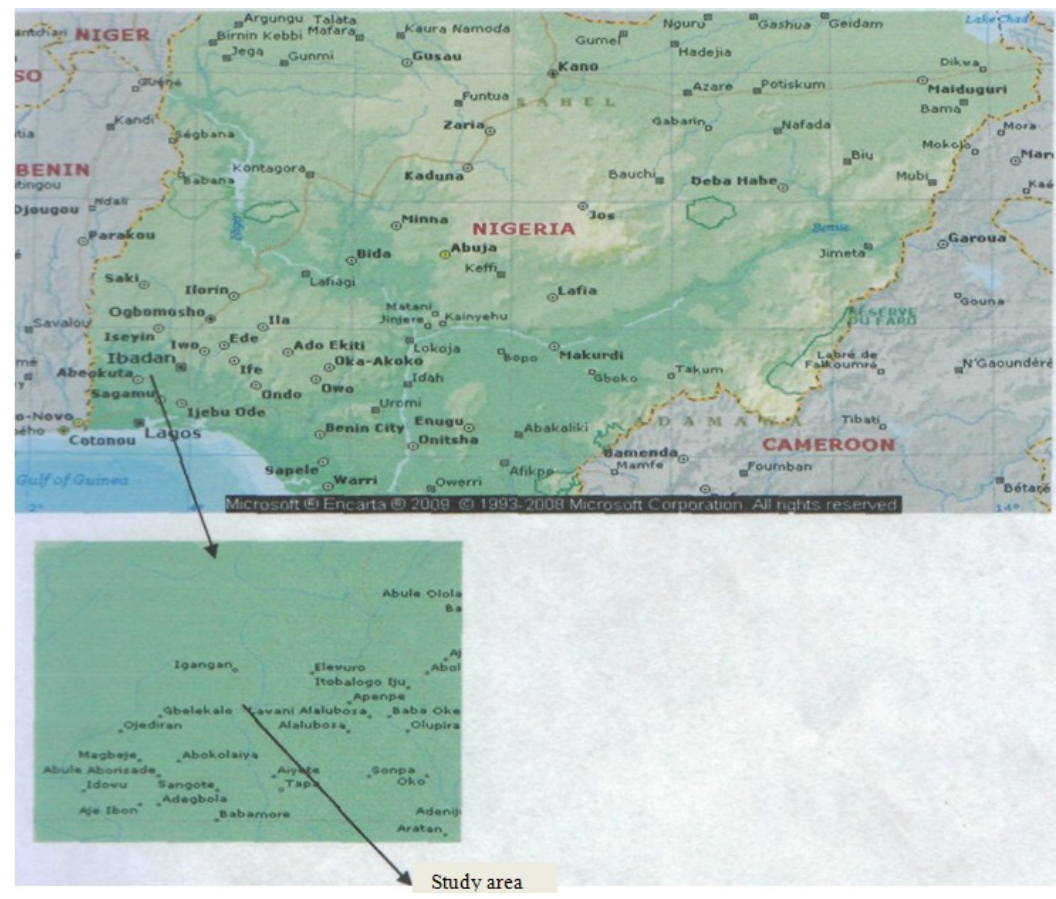

Figure 1: Location map of the study area. 


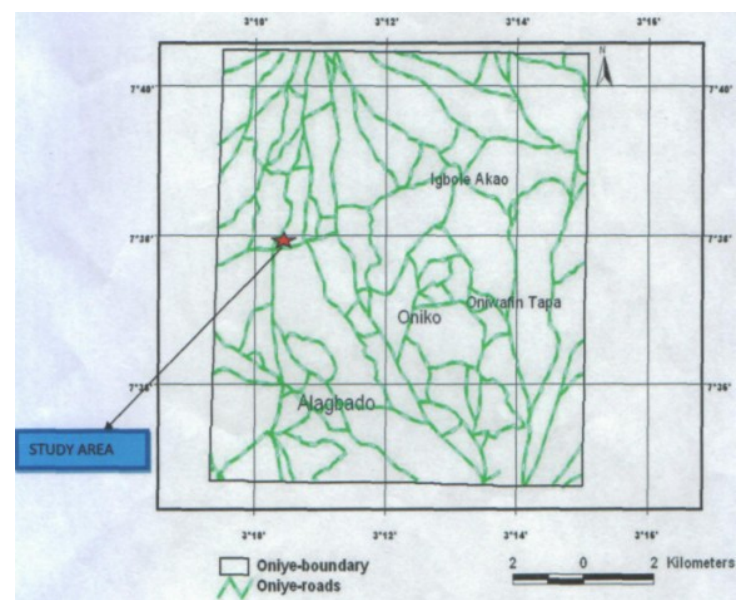

Figure 2: Accessibility map of Oniye showing the study area.

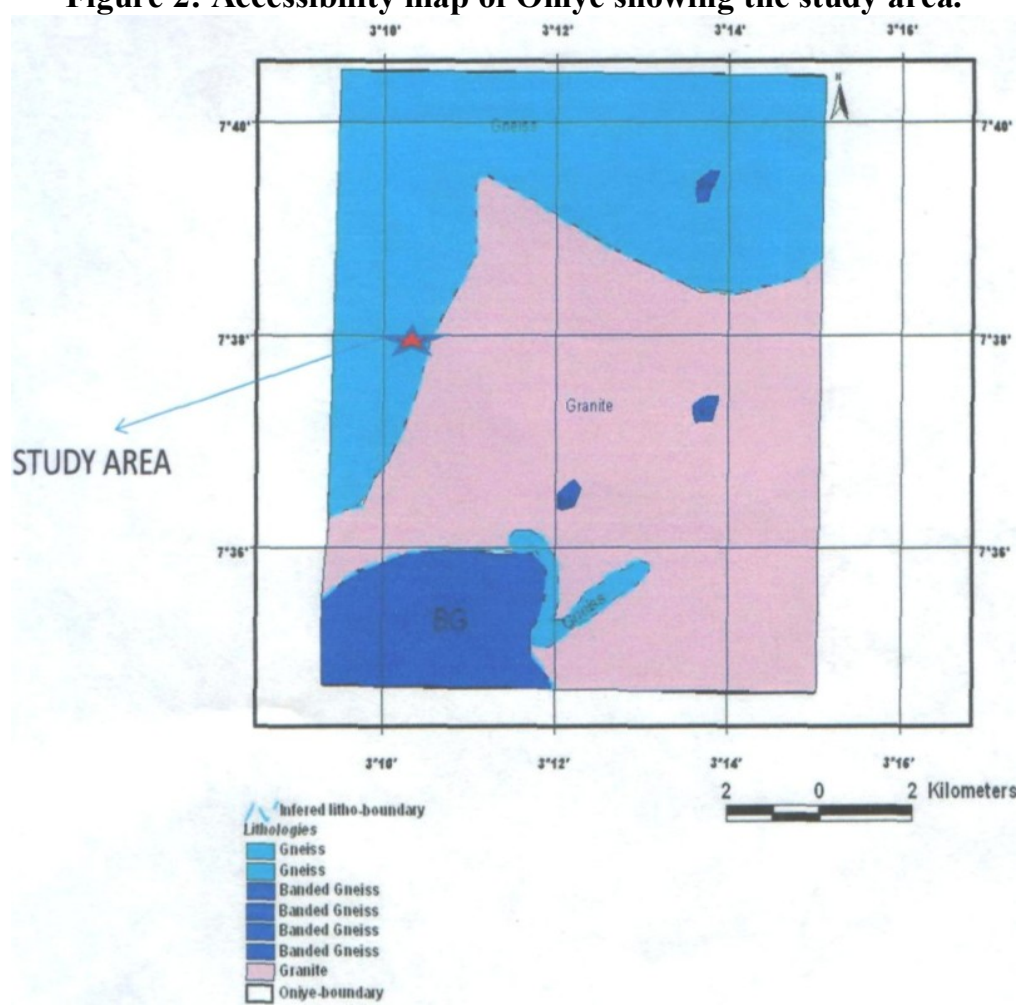

Figure 3: Geologic map of Oniye (after Azeez, 2010).

\section{Materials And Methods Of Study}

The vertical electrical soundings (VES) were conducted using the Schlumberger electrode array (Zohdy et al., 1974). R 50 Resistivity meter was used for the data acquisition. The geoelectric survey comprised of ten depth soundings (Figure 4), with maximum current electrode spacing (AB) of $200 \mathrm{~m}$. The field curves were interpreted through partial curve matching (Koefoed, 1979), engaging master curves and auxiliary point charts (Orellana and Mooney, 1966). The manually derived geoelectric parameters were subjected to an inversion (Vander Velpen, 2004), which successfully reduced the interpretation error to acceptable levels (Barker, 1989). The electrical resistivity contrasts existing between lithological sequences in the subsurface (Doodds and Ivic, 1988; Lashkarripour, 2003) were used in the delineation of geoelectric layers which were used to determine the overburden thickness and to detect the fractured basement within the study area. 


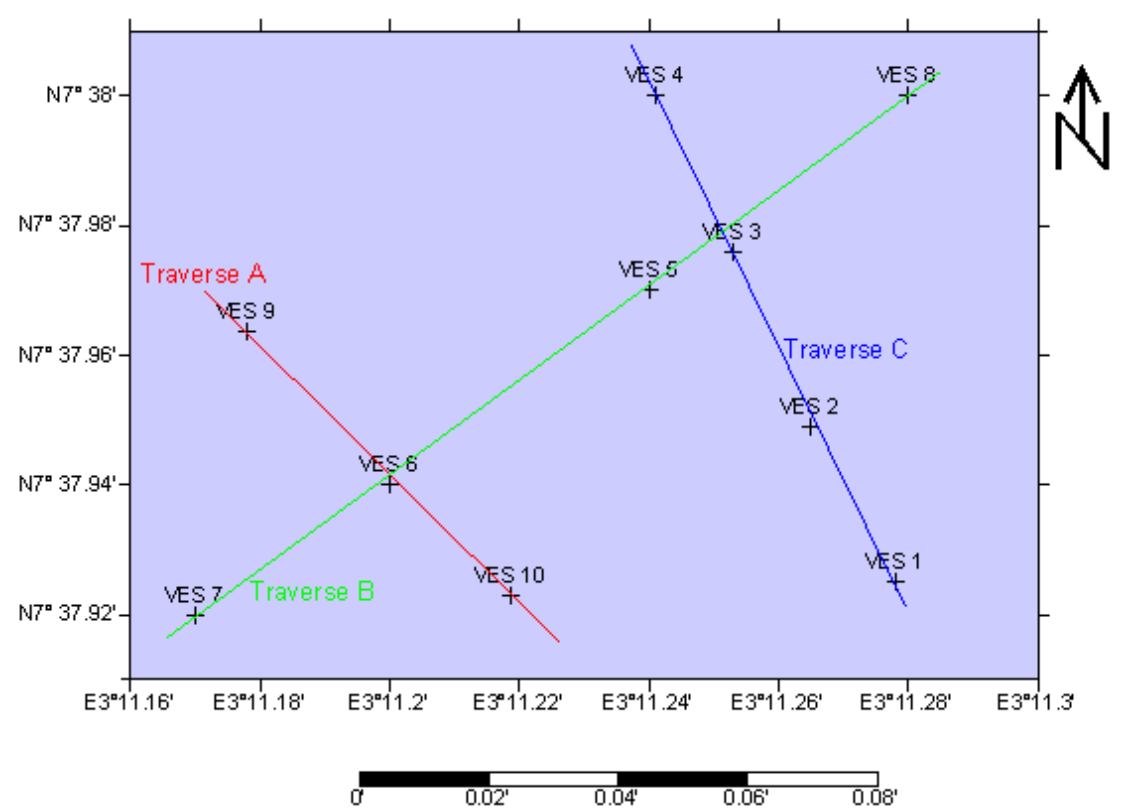

Figure 4: Layout map of VES locations at the study area.

\section{Results And Discussions}

The results were discussed under geoelectric sections, overburden thickness, and resistivity of the bedrock sub-headings. The Schlumberger depth soundings produced a short range of sounding curves: threelayer type A (40\%), H type (50\%), and four-layer curves of type KH (10\%) were recorded. Typical curves are shown in Figure $5(\mathrm{a}-\mathrm{j})$. Summary of the formation of layer parameters and classification of the resistivity sounding curves are presented in Table 1 and 2 respectively.

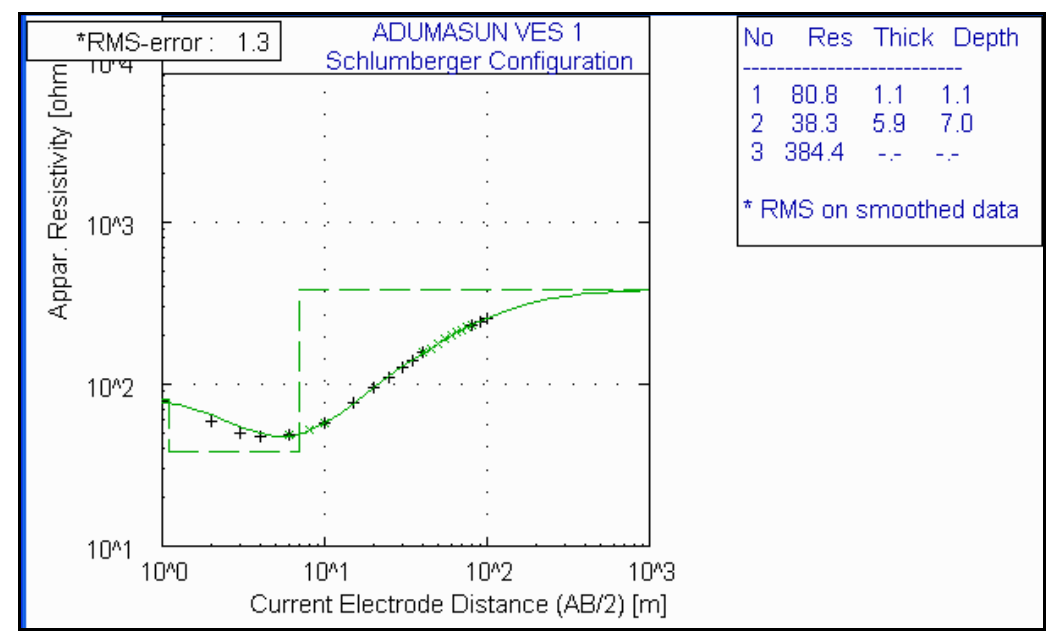

Figure 5(a): The modeled curve for VES 1. 


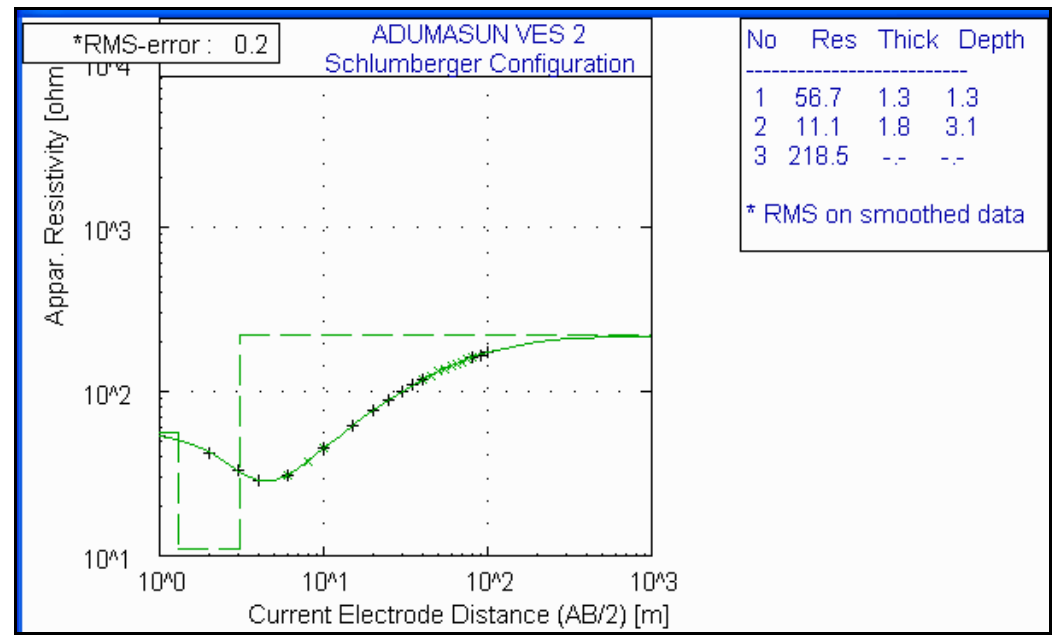

Figure 5(b): The modeled curve for VES 2.

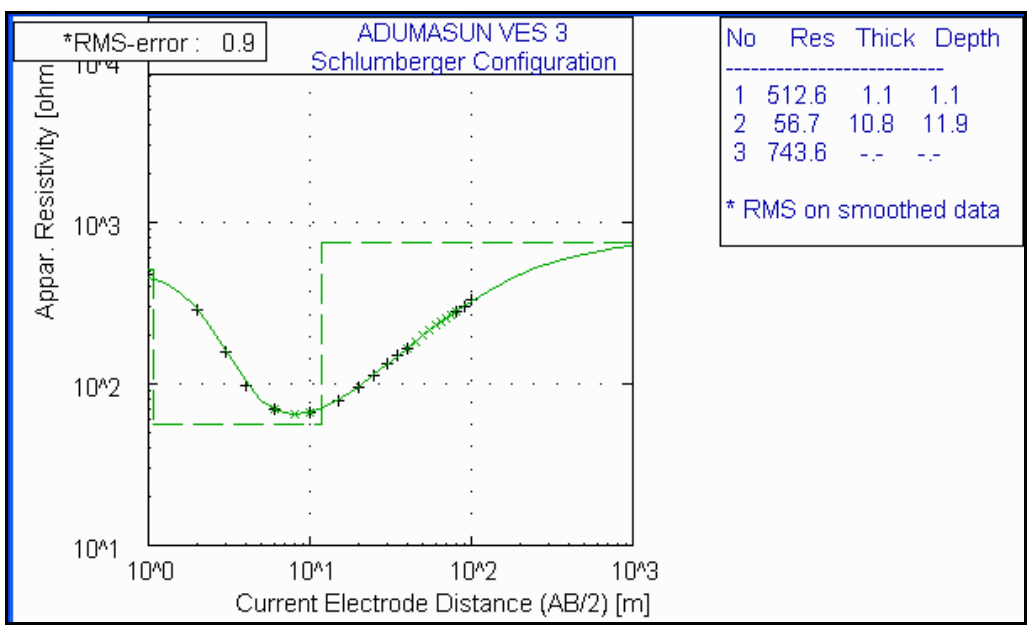

Figure 5(c): The modeled curve for VES 3.

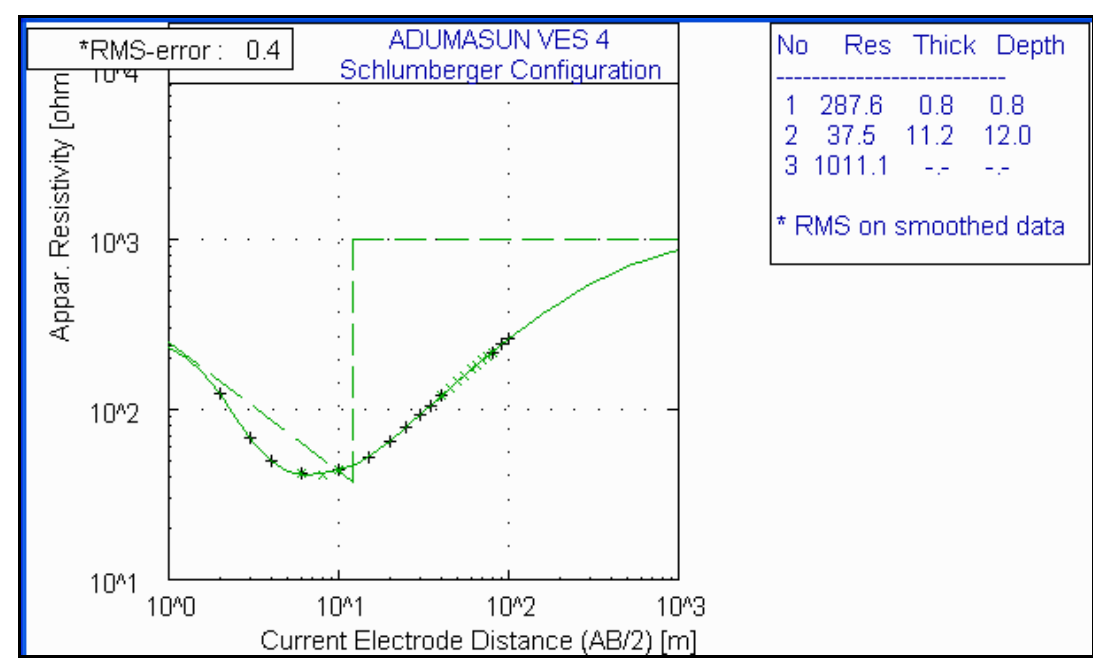

Figure 5(d): The modeled curve for VES 4. 
Vertical Electrical Sounding To Determine Fracture Distribution At Adumasun Area, Oniye,

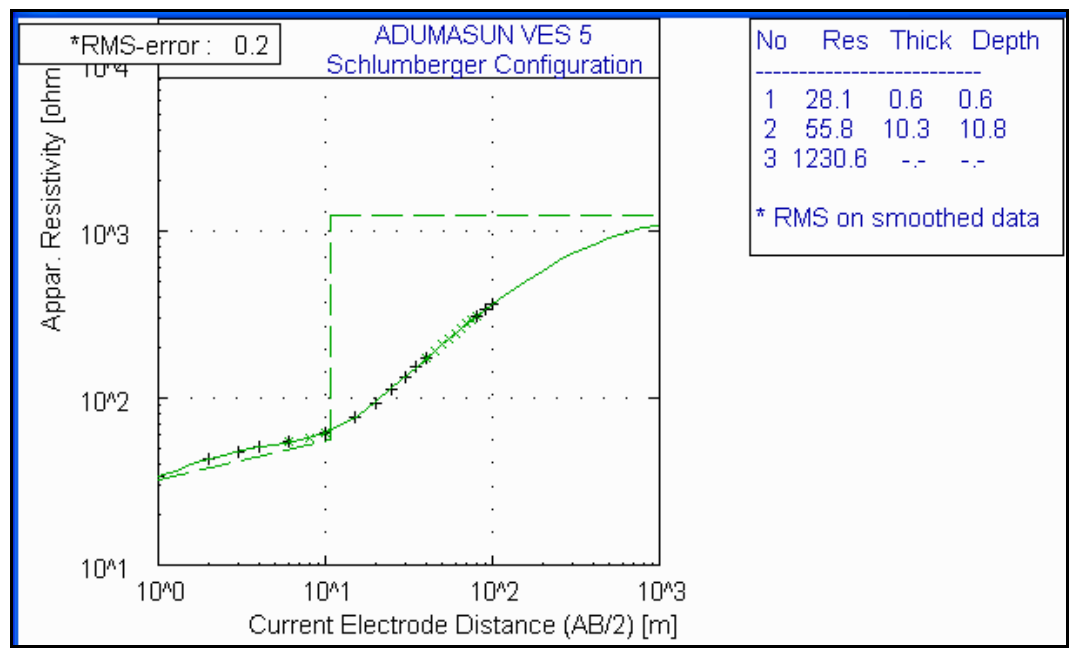

Figure 5(e): The modeled curve for VES 5.

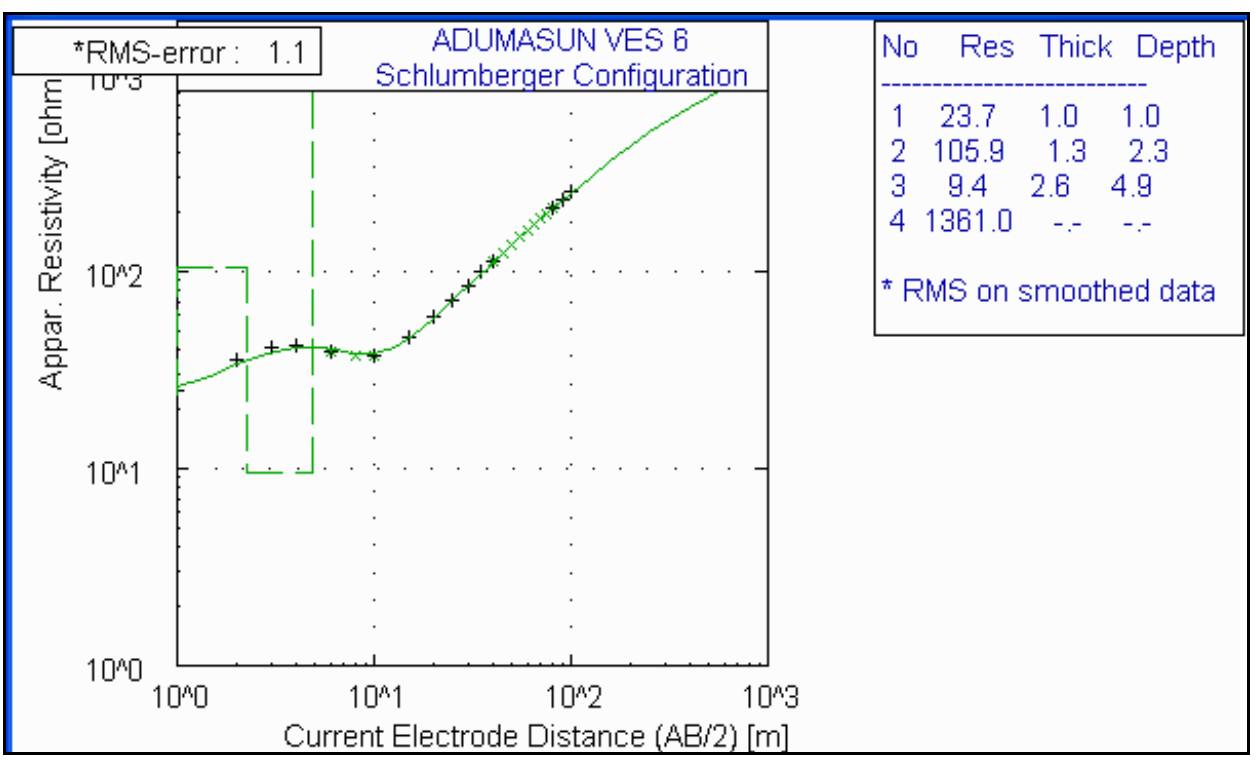

Figure 5(f): The modeled curve for VES 6.

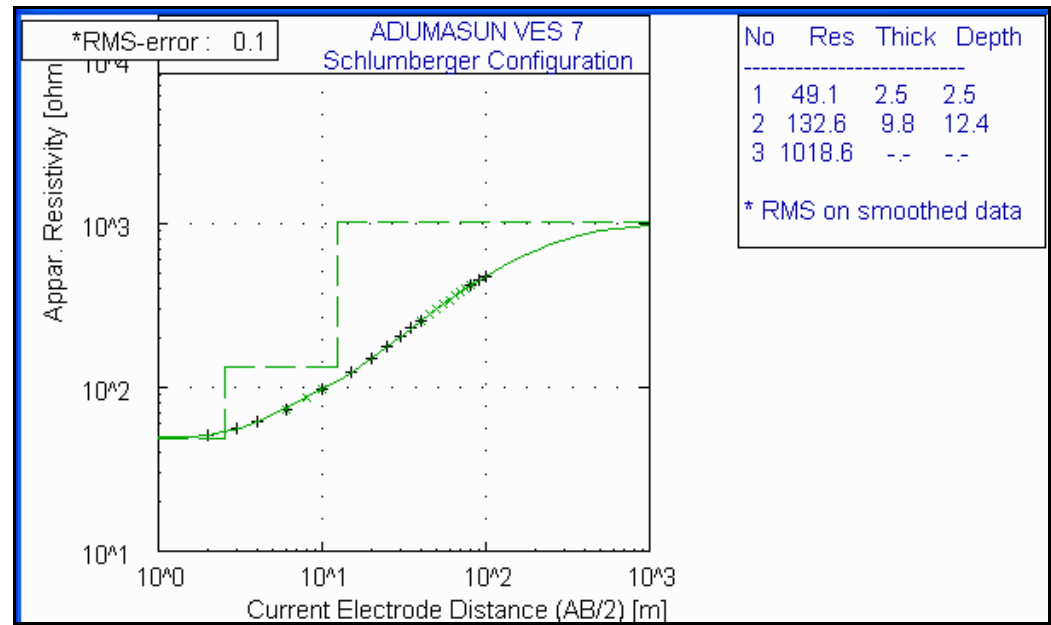

Figure 5(g): The modeled curve for VES 7. 
Vertical Electrical Sounding To Determine Fracture Distribution At Adumasun Area, Oniye,

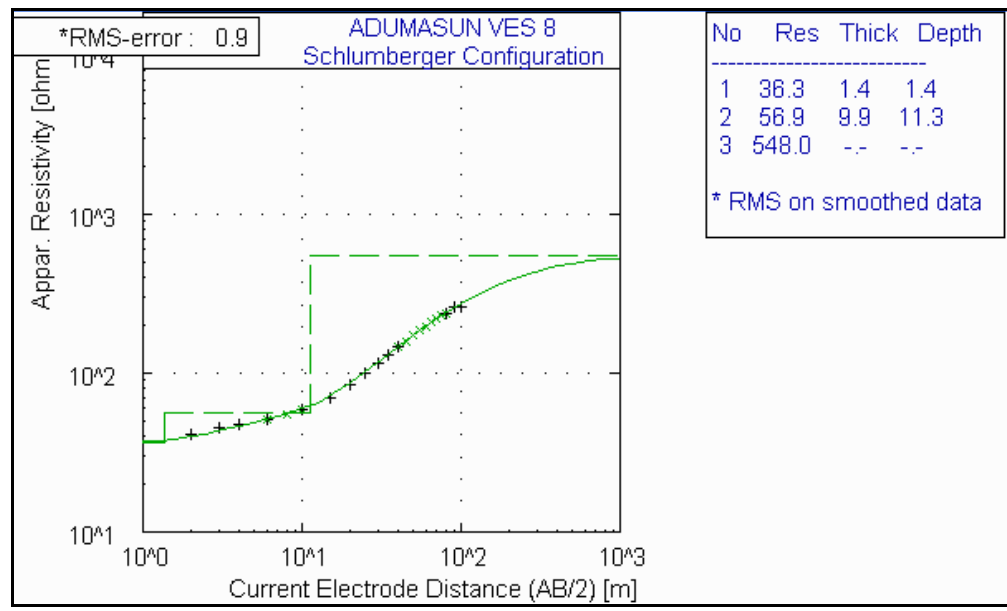

Figure 5(h): The modeled curve for VES 8.

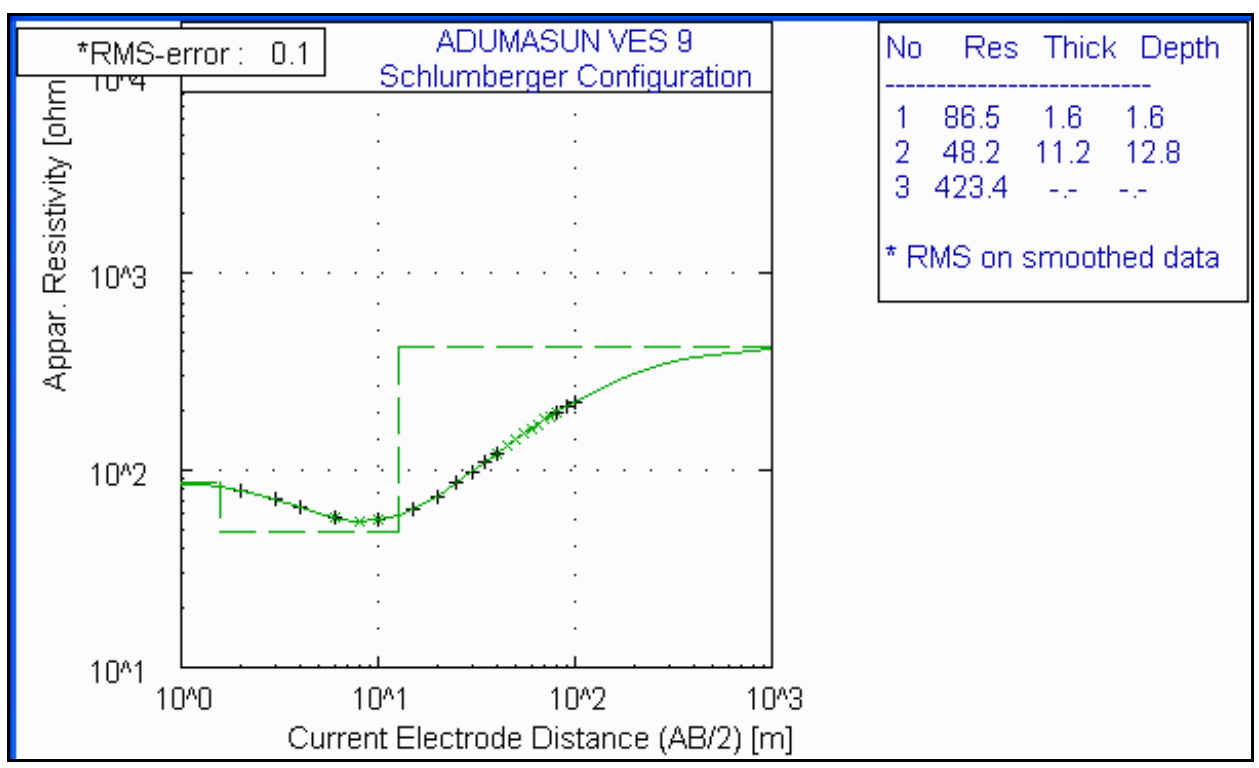

Figure 5(i): The modeled curve for VES 9.

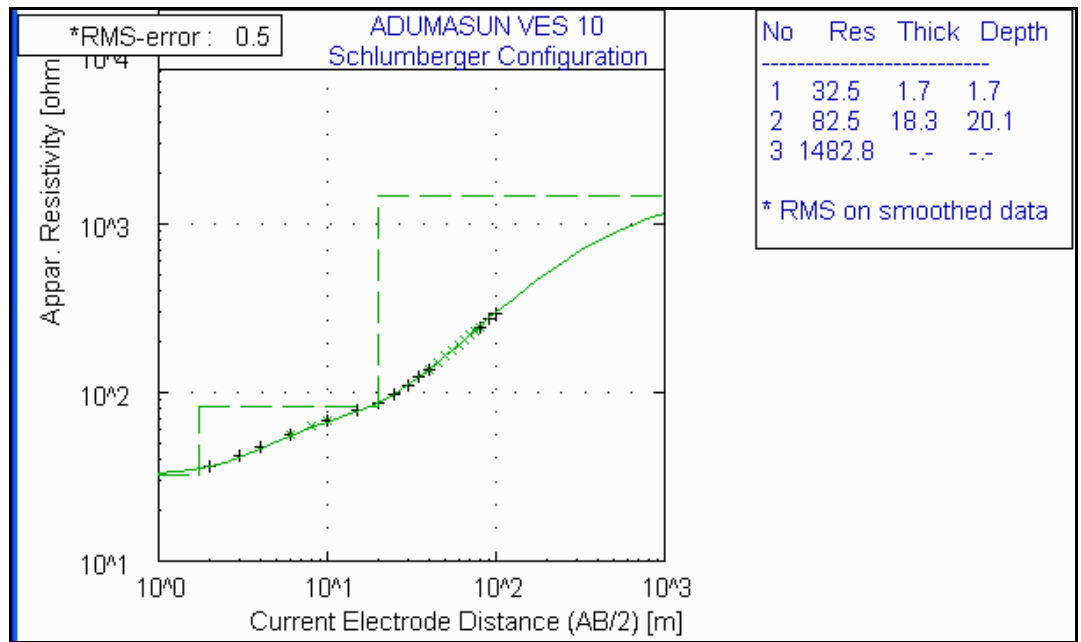

Figure 5(j): The modeled curve for VES 10 .

Table 1: Summary of the formation of layer parameters.

\begin{tabular}{|l|l|l|l|l|l|l|l|}
\hline Location & Layer 1 & & Layer 2 & & Layer 3 & & Layer 4 \\
\hline
\end{tabular}


Vertical Electrical Sounding To Determine Fracture Distribution At Adumasun Area, Oniye,

\begin{tabular}{|l|l|l|l|l|l|l|l|l|}
\hline & $\begin{array}{l}\rho_{1} \\
(\Omega m)\end{array}$ & $\begin{array}{l}\mathbf{h}_{1} \\
(m)\end{array}$ & $\begin{array}{l}\rho_{2} \\
(\Omega m)\end{array}$ & $\begin{array}{l}\mathbf{h}_{2} \\
(m)\end{array}$ & $\begin{array}{l}\rho_{3} \\
(\Omega m)\end{array}$ & $\begin{array}{l}\mathbf{h}_{3} \\
(m)\end{array}$ & $\begin{array}{l}\rho_{4} \\
(\Omega m)\end{array}$ & $\begin{array}{l}\mathbf{h}_{4} \\
(m)\end{array}$ \\
\hline VES 1 & 80.8 & 1.1 & 38.3 & 5.9 & 384.4 & - & - & - \\
VES 2 & 56.7 & 1.3 & 11.1 & 1.8 & 218.5 & - & - & - \\
VES 3 & 512.6 & 1.1 & 56.7 & 10.8 & 743.6 & - & - & - \\
VES 4 & 287.6 & 0.8 & 37.5 & 11.2 & 1011.1 & - & - & - \\
VES 5 & 28.1 & 0.6 & 55.8 & 10.3 & 1230.6 & - & - & - \\
VES 6 & 23.7 & 1.0 & 105.9 & 1.3 & 9.4 & 2.6 & 1361.0 & - \\
VES 7 & 49.1 & 2.5 & 132.6 & 9.8 & 1018.6 & - & - & - \\
VES 8 & 36.3 & 1.4 & 56.9 & 9.9 & 548.0 & - & - & - \\
VES 9 & 86.5 & 1.6 & 48.2 & 11.2 & 423.4 & - & - & - \\
VES 10 & 32.5 & 1.7 & 82.5 & 18.3 & 1482.8 & - & - & - \\
\hline
\end{tabular}

Table 2: Classification of the resistivity sounding curves.

\begin{tabular}{|l|l|l|l|}
\hline Curve types & Resistivity model & Model frequency & VES Locations \\
\hline A & $\rho_{1}<\rho_{2}<\rho_{3}$ & 4 & $5,7,8,10$ \\
$\mathrm{H}$ & $\rho_{1}>\rho_{2}<\rho_{3}$ & 5 & $1,2,3,4,9$ \\
$\mathrm{KH}$ & $\rho_{1}<\rho_{2}>\rho_{3}<\rho_{4}$ & 1 & 6 \\
Total & 10 & \\
\hline
\end{tabular}

\subsection{Geoelectric Sections}

Field curves were mirror-image (geoelectrically) by Surfer 8 (Surfer 8, 2002) in three traverses of SE to NW and SW to NE directions. From figure 4, the 10 VES stations were grouped into 3 profiles (A, B and C) according to how convenient they can be located on a straight line to see an image representation of the subsurface. The results of the interpreted VES curves were used to draw 2D geoelectric sections (figures $6 \mathrm{a}-\mathrm{c}$ ) along profiles $\mathrm{A}, \mathrm{B}$ and $\mathrm{C}$ to show the vertical distribution of resistivities within the volume of the earth in the investigated area. The sections consist of sequence of uniform horizontal (or slightly inclined) layers (horizons). Each layer (horizon) in a geo-electrical section may completely be characterized by its thickness and true resistivity. The geoelectric sections show both vertical and lateral variations in layer resistivity. One of the importances of 2D geoelectric sections is that it helps someone to see clearly where there is thin overburden as well as thick overburden within the sounding locations.

\subsubsection{Profile A}

Geoelectric sections of profile A shows that the area is divided into three-to-four regions (figure 6a). The first, second and third region shows relatively low resistivity (high conductivity) values with the presence of thick overburden beneath VES 10, averagely thin overburden beneath VES 9, very thin overburden beneath VES 6. The basement showed to be fractured beneath VES 9 while VES 6 and VES 10 are underlying with fresh bedrock. VES 9 and VES 10 are recommended for low-rise building with construction of artificial basement before laying of foundation because of thick overburden at VES 10 and fractured present at VES 9. 
Vertical Electrical Sounding To Determine Fracture Distribution At Adumasun Area, Oniye,

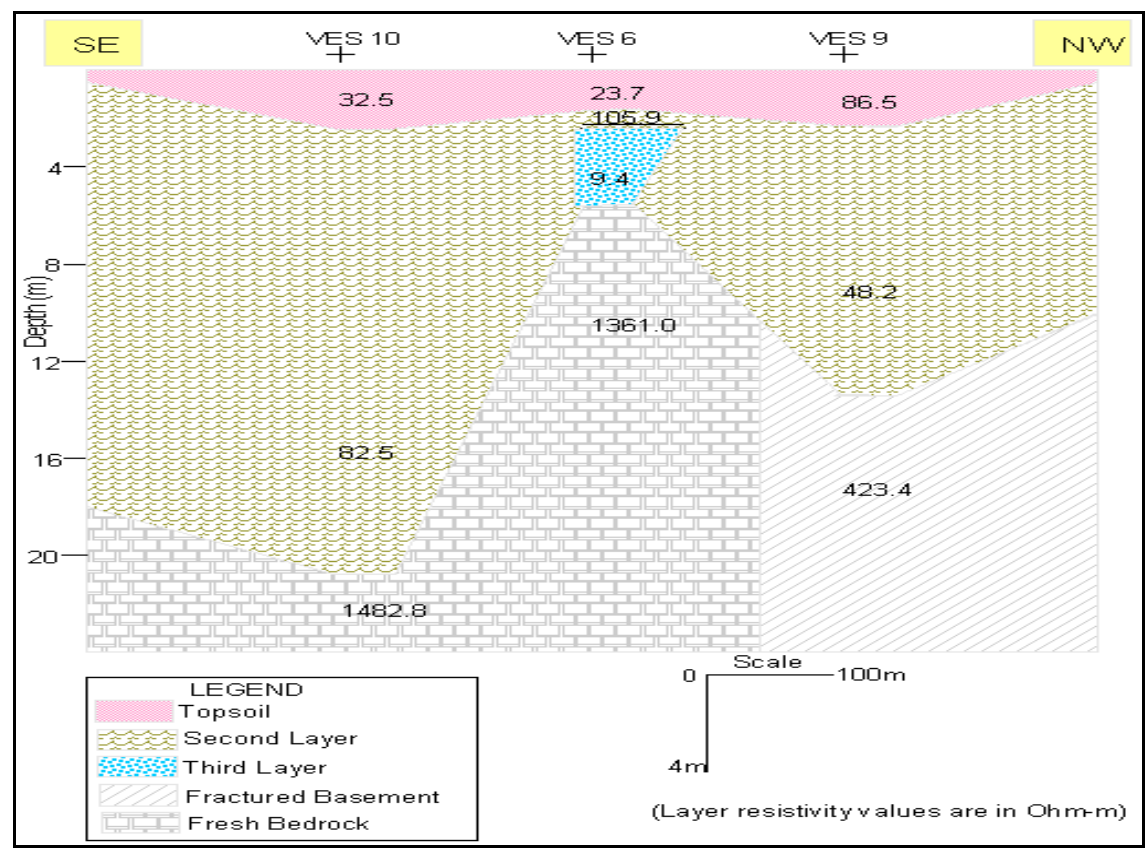

Figure (6a): Geoelectric section along traverse $\mathrm{A}$.

\subsubsection{Profile B}

Geoelectric sections of profile B shows that the area is divided into three-to-four regions (figure 6b). The first, second and third region shows relatively low resistivity (high conductivity) values with the presence of averagely thin overburden beneath this profile. The basement showed to be fractured beneath VES 8 while VES 5 , VES 6 and VES 7 are underlying with fresh bedrock. Since the overburden thickness of VES 5, VES 6 and VES 7 is thin and underlying with fresh bedrock, it is recommended for the construction of both high-rise and low-rise building. However, VES 8 showed an averagely thin overburden with fractured bedrock. This location is only recommended for the construction of low-rise building with construction of artificial basement before the foundation will be laid (Barry, 1999).

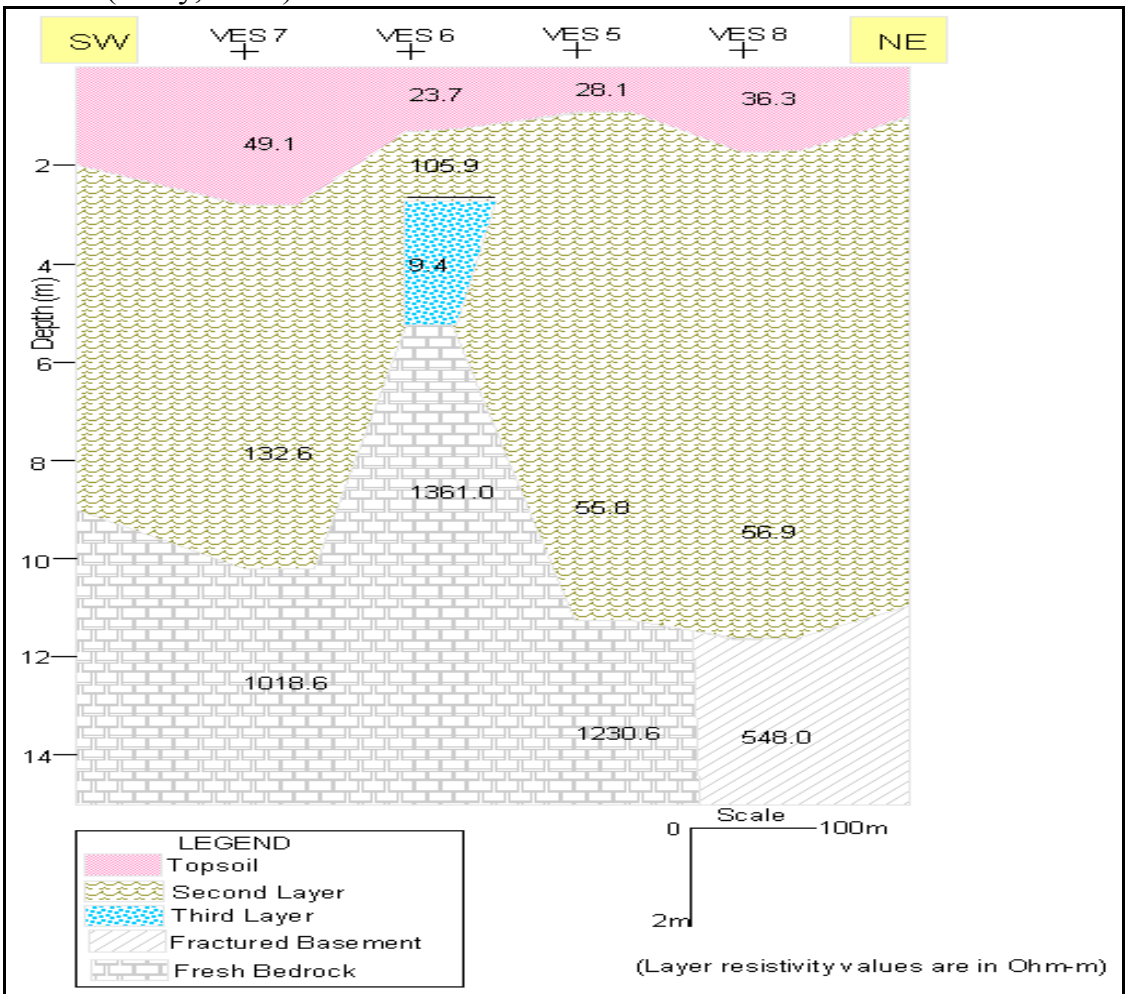

\subsubsection{Profile C}

Figure (6b): Geoelectric section along traverse B. 
Geoelectric sections of profile $\mathrm{C}$ shows that the area is divided into three regions (figure 6c). The first and second region shows relatively low resistivity (high conductivity) values (except for the topsoil resistivity of VES 3 and VES 4) with the presence of averagely thin overburden beneath this profile. The basement showed to be fractured beneath VES 1, VES 2 and VES 3 while VES 4 is only underlying with fresh bedrock. To avoid catastrophic failure in the future, it is therefore recommended not to build high-rise building on this profile because of the fracture in the basement. However, artificial basement should also be constructed before laying the foundation of any building there.

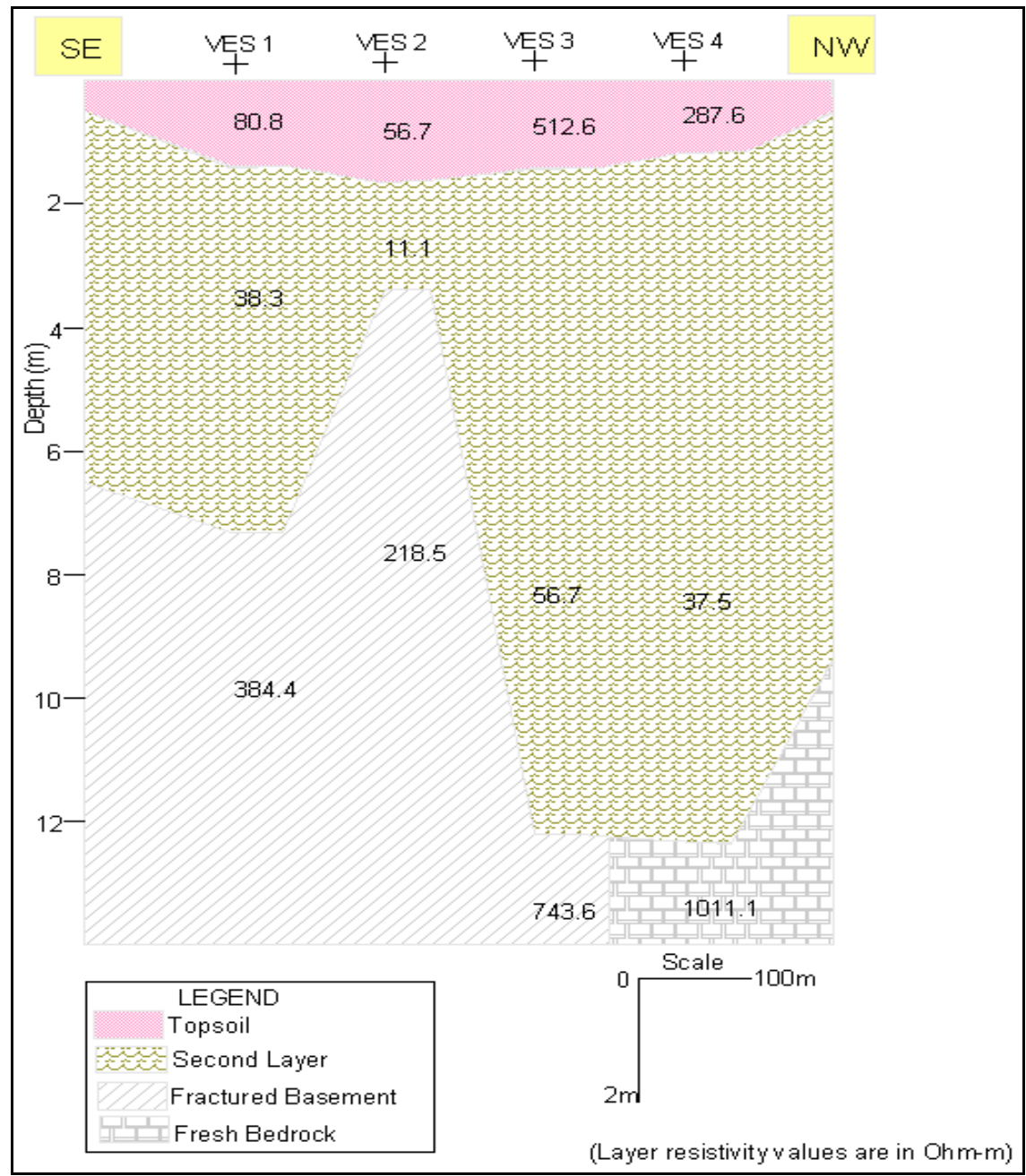

Figure (6c): Geoelectric section along traverse $\mathrm{C}$.

\subsection{Overburden Thickness as Part of Assessment for Basement Competency at Adumasun}

Surface plot of depth to the basement (overburden thickness) beneath the sounding stations were plotted by surfer 8 (Surfer 8,2002 ) as shown in figure 7 . This was done to enable a general view of the subsurface thickness of the surveyed area. The overburden is assumed to include the topsoil, the second layer, and the third layer where it is present. The values range from $3.1 \mathrm{~m}$ to $20.1 \mathrm{~m}$ with an average of $10.63 \mathrm{~m}$. The overburden thicknesses were segmented according to Olayinka et al. (1997). Depth to basement less than $5 \mathrm{~m}$ (demarcated with twilight violet colour) is regarded as thin overburden, depth to basement ranging from $5 \mathrm{~m}$ to $10 \mathrm{~m}$ (demarcated with green colour) is regarded fairly thin, depth to basement ranging from $10 \mathrm{~m}$ to $15 \mathrm{~m}$ (demarcated with pink colour) is regarded as averagely thin or thick (but still moderate), depth to basement greater than $15 \mathrm{~m}$ (demarcated with blue colour) is extremely thick. From the map, overburden thickness ranging from $10 \mathrm{~m}$ to $15 \mathrm{~m}$ constitutes $60 \%$ of the study area. It is therefore recommended that high-rise building should not be compacted on Adumasun land. 


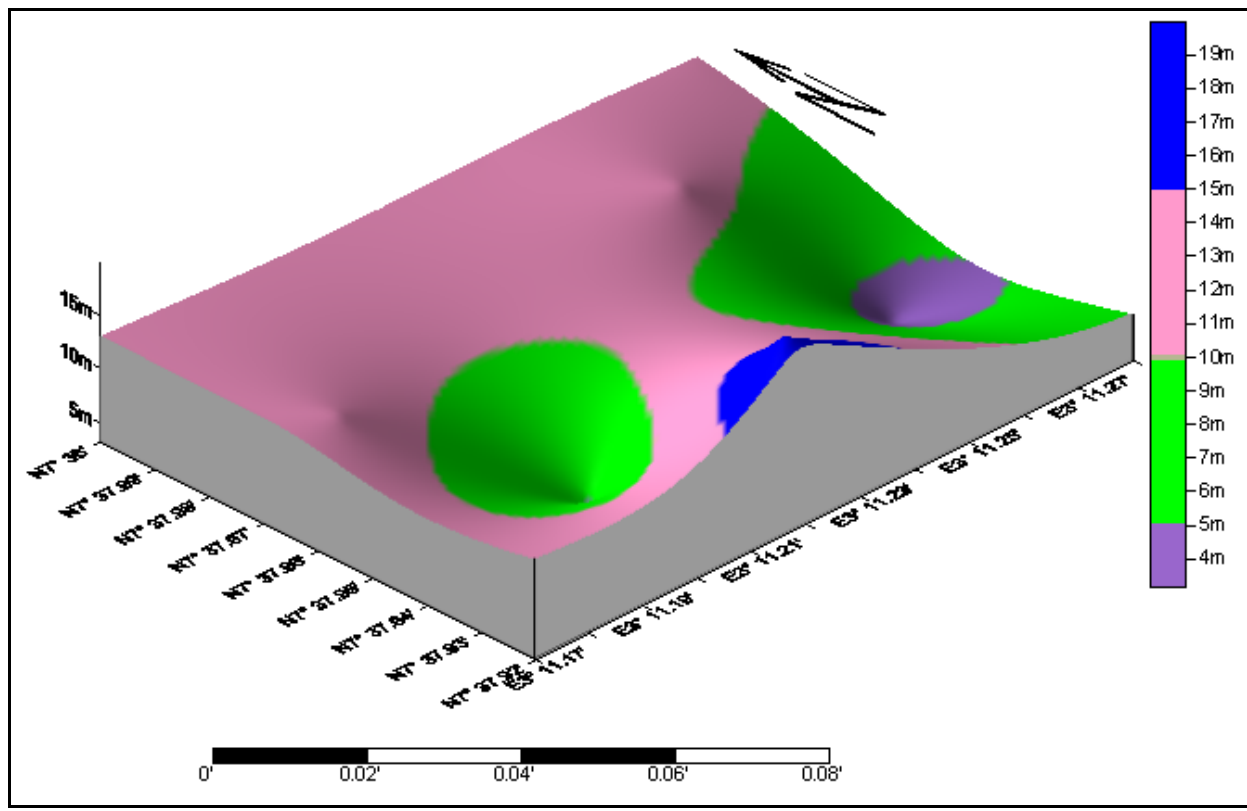

Figure 7: Surface (3-D) plot of overburden thickness at Adumasun.

\subsection{Bedrock Resistivity as Part of Assessment for Fracture Detection at Adumasun}

Past study from Olayinka and Olorunfemi (1992) (Olayinka and Olorunfemi, 1992) showed that resistivity of fresh bedrock often exceeds $1000 \Omega \mathrm{m}$ while the resistivity of fractured basement which is probably saturated with fresh waters often reduces below $1000 \Omega \mathrm{m}$. This has been adopted to construct surface map of bedrock resistivity at Adumasun (figure 8). Resistivity less than $1000 \Omega \mathrm{m}$ is demarcated with colour red while resistivity greater than $1000 \Omega \mathrm{m}$ is demarcated with colour blue. From the map, one-third of the study area showed fresh bedrock while two-third showed fractured bedrock from the general view. This shows that Adumasun is not totally competent for the construction of high-rise buildings.

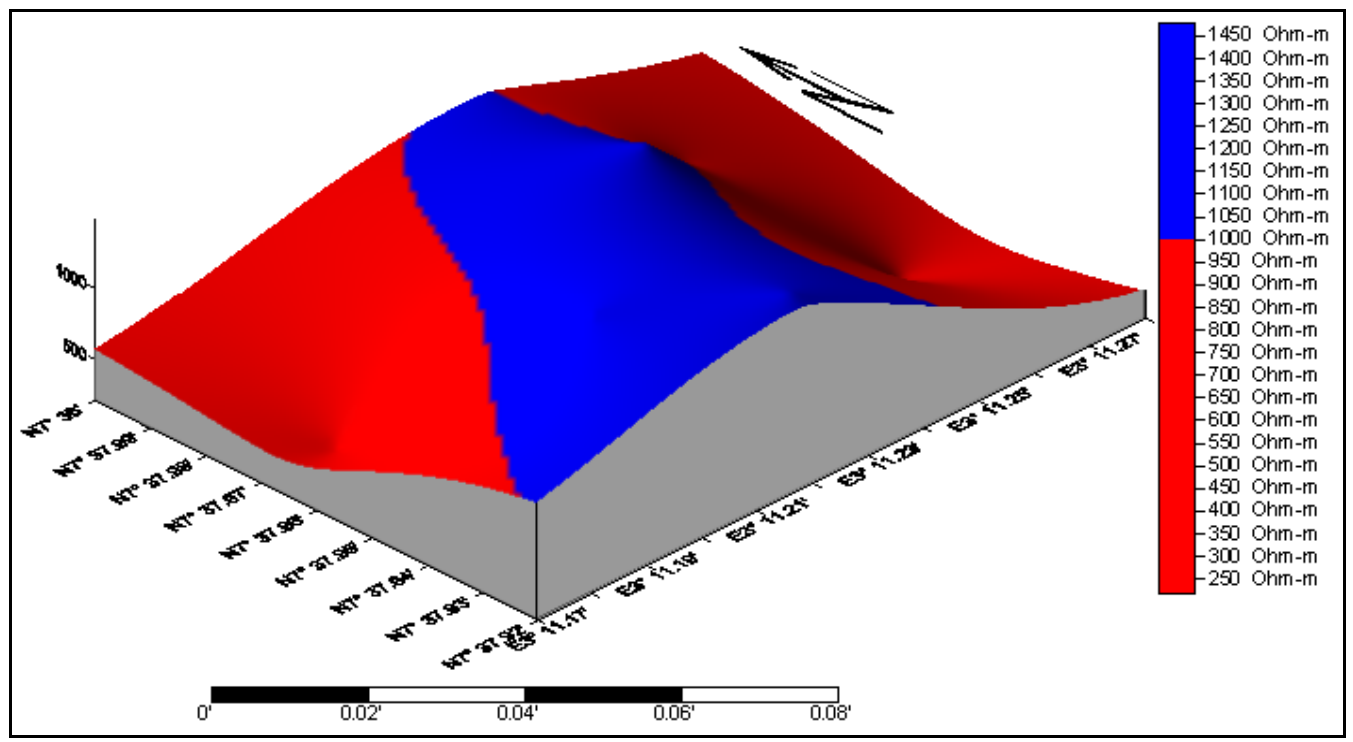

Figure 8: Surface (3-D) plot of bedrock resistivity at Adumasun.

\section{Conclusion}

The study has been able to highlight the importance of vertical electrical sounding in determination of fractured distribution in the basement and to determine the overburden thickness of the study area. Electrical Resistivity method has advantage over other geophysical methods in that it can laterally and vertically delineate the subsurface depending on the configuration used. This study has adopted vertical delineation into subsurface which can only be achieved by Vertical Electrical Soundings. Its cost is also cheap compare to other geophysical survey that can be used to map the subsurface layers (e.g. seismic method). Groundmagnetic and 
Electromagnetic method can not be used to delineate vertically but it is good as reconnaissance study in lateral delineation which was not the purpose of this study. A multidimensional approach to this study (that is modeled curves, geoelectric sections, overburden thickness assessment, and bedrock resistivity assessment) has made the study both very qualitative and quantitative as information missed by any of the methods is revealed by the other and thereby necessitating justifiable conclusions. Overburden thickness of the study area ranging from $3.1 \mathrm{~m}$ to $20.1 \mathrm{~m}$ with an average of $10.63 \mathrm{~m}$. From figure 7 and 8 , areas underlying with fresh bedrock and thin overburden thickness are recommended for the construction of high-rise buildings while areas with fractured basement and thick overburden thickness are recommended for the construction of low-rise buildings. It is recommended that other relevant geophysical methods be used in the study area so as to confirm the fractures pattern predicted in this study.

\section{References}

[1] Barry S. (1999): The construction of buildings. Blackwell Science Ltd. Volume 1, seventh edition.

[2] Adagunodo TA. (2012): Interpretation of Groundmagnetic and Vertical Electrical Sounding Data in the Study of Basement Pattern of an Industrial Estate in Ogbomoso, Southwestern Nigeria. M.Tech Thesis, Ladoke Akintola University of Technology, Ogbomoso, Nigeria.

[3] Adagunodo Aanuoluwa and Sunmonu Ayobami. (2013): The Study of Basement Pattern of an Industrial Estate. Germany: Lambert Academic Publishing GmbH \& Co. KG. Pp 1.

[4] Oladejo OP. (2012): The Site Characterization of Oyo State Housing Estate, Ogbomoso Southwestern Nigeria using Vertical Electrical Sounding and Very Low Frequency Techniques. M.Tech Thesis, Ladoke Akintola University of Technology, Ogbomoso, Nigeria.

[5] Ayininuola GM, and Olalusi OO. (2004): Assessment of building failures in Nigeria: Lagos and Ibadan Case Study. Africa Journal of Science and Technology. 5(1), 73-78.

[6] Roddis WMK. (1993): Structural Failures and engineering Ethics, Journal of structural Engineering-ASCE. 119(5), 1539-1555.

[7] Wardhama K, and Hadiprino FC. (2003): Study of recent building failures in the United States, Journal of Performance of Constructed Facilities. 17(3), 151- 158.

[8] Bazart ZP, and Verdue M. (2006): Mechanics of progressive: Collapse: learning from World Trade Center and Building demolitions, report no. 06/06/c605 T, Department of Civil and Environmental engineering, Northwestern University, Evanston, Illinois 60208, USA.

[9] Nwankwo LI, Olasehinde PI, and Babatunde EB. (2004): The use of Electrical Resistivity Pseudo-Section in elucidating the Geology of an East-West profile in the basement complex terrain of Ilorin, West-Central, Nigeria, Nigeria Journal of Pure and Applied Sciences. 19: 1676-1682.

[10] Alagbe OA. (2005): Integration of Electrical Resistivity Techniques and Lineament analysis in Hydrogeological investigation of parts of Ogbomoso, South - Western Nigeria. M.Tech Thesis, Ladoke Akintola University of Technology, Ogbomoso, Nigeria.

[11] Ayantunji BG. (2005): Integrated use of electrical and electromagnetic (VLF) method in the delineation of the fault pattern of Odokoto, Ogbomoso, Southwestern Nigeria. M.Tech Thesis, Ladoke Akintola University of Technology, Ogbomoso, Nigeria.

[12] Adelusi AO, Adiat KAN, and Amigun JO. (2009): Integration of subsurface electrical prospecting methods for fracture detection in Precambrian Basement rocks of Iwaraja area Southwestern Nigeria, Ozean Journal of Applied Sciences. 2(3): 265-280.

[13] Omosuyi GO. (2010): Geoelectric assessment of groundwater prospect and vulnerability of overburden aquifers at Idanre, Southwestern Nigeria, Ozean Journal of Applied Sciences. 3(1): 19-28.

[14] Koefoed O. (1979): Geosounding Principles, 1. Resistivity sounding measurements. Elsevier Scientific Publishing Comp., Amsterdam, 275.

[15] Zohdy AAR, Eaton GP, and Mabey DR. (1974): Application of surface geophysics to groundwater investigations: Techniques of water resources investigations of U.S. Geolo. Survey: Book 2, Chapter D1, U.S. Government Printing Office, Washington. 66.

[16] Ajibade AC, and Fitches WR. (1988): The Nigeria Precambrian and the Pan-African Orogeny. In: Precambrian Geology of Nigeria. A publication of the Geological Survey of Nigeria. Pp 329.

[17] Ajibade AC, Rahaman MA, and Ogezi AEO. (1988): The Precambrian of Nigeria, a Geochronological Survey. Publication of the Geological Survey of Nigeria.

[18] MacDonald AM, and Davies J. (2000): A brief review of groundwater for rural water supply inSub-Saharan Africa. B.G.S. Technical Report. W.C./00/33.

[19] Azeez YO. (2010): Geological mapping of Oniye, Oyo State, Nigeria. Unpublished 500 Level geological mapping. Department of Earth Sciences, Ladoke Akintola University of Technology, Ogbomoso, Oyo State, Nigeria. 2010.

[20] Orellana E, and Mooney HM. (1966): Master tables and curves for vertical electrical sounding over layered structures. Inteciencis, Madrib. 34.

[21] Vander Velpen BPA. (2004): WinRESIST Version 1.0. Resistivity Sounding Interpretation Software. M.Sc. Research Project, ITC, Delft Netherland.

[22] Barker RD. (1989): Depth of investigation of collinear symmetrical four-electrode arrays. Geophysics. 54: $1031-1037$.

[23] Dodds AR, and Ivic D. (1988): Integrated geophysical methods used for groundwater studies in the Murray Basin, South Australia. In Geotechnical and Environmental Studies. Geophysics; Vol

[24] Lashkarripour GR. (2003): Journal of Spatial Hydrology. 3(1): 1-5.

[25] Surfer 8, Version 8.01. (2002): Surface mapping system. Golden Software Inc, Colorado.

[26] Olayinka AI, Akpan EJ, and Magbagbeola OA. (1997): Geoelectric sounding for estimating aquifer potential in the crystalline basement area around shaki, southwestern Nigeria. Water Resources- Journal of NAH. 8(1 \&2): 71-81.

[27] Olayinka AI, and Olorunfemi MO. (1992): Determination of geoelectrical characteristics in Okene area and implications for borehole siting. J. Mining Geol. 2(28): 403-412. 